\title{
Effect Of Baby Spa On Sleep Quality of Baby 3-6 Months
}

\author{
Anisa Oktapiani ${ }^{1)}$; Siti Patimah2) ); Etin Rohmatin ${ }^{3)}$ \\ Anisaoktapiani1@gmail.com
}

\begin{abstract}
Background: Infancy was a golden period for children's growth and development, so it needs special attention. One of the factors that influence a baby's growth and development was sleep and rest. If the baby's sleep was disrupted then the child's physical growth will be disrupted, the cognitive and emotional development of the baby will be disrupted and this will affect the development of the brain and the potential that should develop will be lost. Baby spa was one of the useful non-pharmacological therapies which was to increase the concentration of the baby and make the baby sleep well. The aim of this study was to determine the effect of Baby Spa on sleep quality of infants 3-6 months.

Methods: The design of this research was pre-experimental, one group pretest-post use a brief infant sleep questionnaire (BISQ). The sampling technique was purposive sampling with a sample of 31 infants. Statistical analysis used wilcoxon signed rank test.

Results: Results of studies that had been carried out obtained frequency of sleep quality is $p=0,001$. That suggests baby spa were effective for improving sleep quality.

Conclusion: Baby SPA was effective for improving the quality of sleep for infants 3-6 months. for mothers who had babies to add insight about the Baby Spa, because Baby Spa had many benefits, including regular sleep patterns
\end{abstract}

Keyword : baby spa, sleep quality, baby 3-6 months

1,2,3) Midwifery Department, Poltekkes Kemenkes Tasikmalaya Indonesia

Jl. Babakan Siliwangi No.35, Kahuripan, Kec. Tawang, Tasikmalaya, Jawa Barat

Background. Infancy was a golden period for children's growth and development, so it needs special attention. One of the factors that influence a baby's growth and development was sleep and rest. Good night's sleep was very important for baby's growth, because during sleep the baby's brain growth reaches it was peak. Also during sleep the baby's body produces growth hormone three times more when the baby was sleeping than when the baby woke up (Lilik, 2015).

Infants at the age of 3-6 months the number of naps decreases, about 3 times and continues to decrease. The total amount of sleep between 13-15 hours / day. At the age of 6 months his sleep patterns begin to look similar to adults. After setting a period that generally takes 10 to 20 minutes, the baby's sleep changes in stages, from stage one nonREM to stage three or four. Babies may return to stage one and roll back after one or two NREM sleep cycles, REM begins to occur after 60 to 90 minutes (Lilik, 2015).

If the baby's sleep was disrupted then the child's physical growth will be disrupted, the cognitive and emotional development of the baby will be disrupted and this will affect the development of the brain and the potential that should develop will be lost. Disturbances will also appear on the baby's own motor, gross motor motion was more developed than fine motoric. And the influence on mental and emotional sleep-deprived babies will be easily fussy (Guyton, 2012).

According to Health Law Number. 36/2009, infant massage is a traditional health service that is included in this type of skill. This baby massage in accordance with the Minister of Health Regulation No. 1109 of 2007 can be categorized into alternative complementary medicine because it has been obtained through structured education based on biomedical science. Baby massage is a form of movement play in infants, to stimulate growth and development as well as the ability to move the baby optimally (Sutini, 2008) baby massage was a series of baby spas, health minister regulation number 2014 regarding SPA services (Widodo, 2013)

In 2017, the total number of babies in Tasikmalaya City was 5954 babies in Tasikmalaya City. (City of Health Tasikmalaya, 
2017). In 2018 the number of infants 3-6 months 216 babies was recorded at Mangkubumi Health Center (Dinkes Kota Tasikmalaya, 2017)

After conducting a preliminary study in the working area of the Mangkubumi Community Health Center on December 20, 2018. Conducting interviews with questionnaires to 10 mothers of infants aged 3-6 months get the results of these interviews found 2 infants (20\%) did not experience sleep disorders and 8 infants $(80 \%)$ experiencing sleep quality disorders.

Sleep disorders in babies must be addressed immediately to support their growth and development. Baby spa was a series of activities given to babies with the aim of providing relaxation to the baby as well as providing physical needs, useful for brain growth, sensory systems, emotions, affection and stimulus stimuli through touch with a massage. Baby spa can be used as an option to treat sleep disorders in babies. So that further research is needed on the effect of baby spa on the quality of baby sleep.

The aim of this study was to determine the effect of Baby Spa on sleep quality of infants 36 months in the area of the Mangkubumi Community Health Center in Tasikmalaya City

Methods. This type of research was preexperimental with One Group Pretest-Posttest Design. The study was conducted in the Mangkubumi Community Health Center in Tasikmalaya City in January-February 2019. The population in this study was 3-6 Months Infants in the Mangkubumi Community Health Center in Tasikmalaya City, with a sample of 31 infants 3-6 months who disturbed the quality of sleep, taken by purposive sampling. The data collection method was carried out by measuring sleep quality using the A Brief Screaning Qustionare (BISQ) questionnaire. Babies do Baby Spa 4 times a month. After the intervention completed then the baby is remeasured related to sleep quality. To find out the relationship between variables using the Wilcoxon test.

\section{Result and Discussion.}

Sleep quality in infants aged 3-6 months before the baby spa procedure.

There were 29 people $(93.75 \%)$ have mild problems, and 2 babies $(2.25 \%)$ have severe problems. This is because the findings at the study site found that mothers do not yet know the comfort of baby's sleep so that the quality of baby's sleep was still many who have quality baby sleep that has problems.

According to Lilik (2015) sleep comfort and sleep patterns infant was related to age and brain maturity, so the total amount of sleep needed is reduced will be followed by a decrease in the proportion of rapid eyes movement (REM) and non-REM. In the REM phase there was an increase in blood flow to the brain resulting in better brain function, brain cells grow faster, and this will affect the restoration of emotional and cognitive functions.

Based on the description above, it can be harmonized with the results of research that one of the problems in sleep quality was comfort so that it disrupts the quality of baby's sleep.

\section{Sleep quality in infants aged 3-6 months after the Baby SPA procedure}

Sleep quality in infants aged 3-6 months after the baby spa therapy as many as 28 $(90.32 \%)$ did not experience problems in sleep quality, and $3(9.68 \%)$ experienced mild problems.

This was because with a baby spa the baby feels comfortable and the baby's muscle stretches were very relaxed so that the baby was more comfortable in resting and the quality of sleep was better.

Widodo (2013) said that one technique that was able to support the stimulation of children's growth and development was a touch of love with a baby spa. The benefits of this baby spa can provide a sense of calm, comfort, and fresh. The impact of water generated from turbulent water can provide sensations and massages that eliminate fatigue, improve blood circulation and create relaxation. Thus the baby will sleep more soundly so that it can increase the number of hours of sleep day and night. Where in the baby's sleep there was an increase in hormone expenditure.

\section{Effects of Baby Spa on Sleep Quality for Babies 3-6 Months}

The change in the average frequency of sleep quality for babies before the baby spa who had minor problems was 29 people $(93.55 \%)$ and after the action was done, the condition improved, there were 28 babies who did not experience sleep problems (90.32\%). Wilcoxon test result show that $\rho$ value was 0,000 . Its means that there was an effect of Baby Spa on the quality of sleep for babies 3-6 months. 
Spa was a Latin expression of salus per aqua which literally means healthy through water. Baby spa was a series of activities given to babies with the aim of providing relaxation to the baby as well as providing physical needs, useful for brain growth, sensory systems, emotions, affection and stimulus stimuli through touch with a massage.

Gentle massage was a form of stimulation in the form of touch intended for the growth and development of the baby. The gentle touch and pressure of the baby's massage cause the nerve endings found on the surface of the skin to cause a reaction. Furthermore, these nerves send messages to the brain through the neural network that was in the spinal cord. Gentle massage will help relax the muscles and reduce the hormone adrenaline so that you sleep soundly. 3-6 months old baby was one of the right times for babies to start doing baby spa. (Galenia MCC, 2014; Irianto, 2014).

Baby spa has many benefits for babies, namely regular sleep patterns, stimulates and balances the hormones cortisol and oxytocin, improves the baby's immune system so that it makes the baby healthier, stimulates enzymes in the stomach so that absorption of nutrients in the body was more optimal, stimulates hormones that have an effect on increasing the baby's appetite, namely the gastrin hormone, improving blood circulation and helping strengthen the muscles of the baby, preventing the baby from experiencing bloating and colic, affecting the brain development optimally and healthy organs and optimizing the ability of sensory organs, such as the sense of touch, smell vision, hearing and balance. So therefore Baby Spa can be interpreted as a series of activities given to babies with the aim of providing relaxation to the baby (Rini, 2014).

There was an influence between the baby spa on the length of sleep of infants aged 3-4 months. Tang \& Aras also stated that there is an influence between baby massage on the quality of sleep of infants aged 1-4 months.

Conclusion and Suggestions. Baby SPA was effective for improving the quality of sleep for infants 3-6 months $(p=0.000)$. Suggestions for mothers who had babies to add insight about the Baby Spa, because Baby Spa had many benefits, including regular sleep patterns

Acknowledgements. Thanks to the researchers say to all those who have helped in completing this research.

\section{References}

Dinkes Kota Tasikmalaya 2017, Tumbuh kembang anak dan jumlah balita

Guyton AC, Hall JE. (2012), Buku ajar fisiologi kedokteran edisi revisi, EGC, Jakarta

Kementrian kesehatan RI. ( 2017 ), Laporan jumlah bayi di Indonesia dan jawa barat tahun 2018, Terdapat dalam : http://www.pusdatin.kemenkes.go.id/reso urces/download/pusdatin/profilkesehatan-indonesia-2017.pdf, diakses : 20 Desember 2018

Mardiana L, Martini DE. (2015). Pengaruh pijat bayi terhadap kuantitas tidur bayi usia 3-6 bulan di desa Munungrejo kecamatan Ngimbang kabupaten Lamongan. Surya

Maharani, Sabrina, (2009), Pijat dan Senam Sehat Untuk bayi, Kata Hati, Jogjakarta

Marliany, Roesleny. (2010), Psikologi Umum Pustaka Setia, Bandung

Peraturan Menteri Kesehatan nomor tahun 2014 tentang pelayanan SPA. Terdapat dalam https://www.scribd.com/doc/242237407/P MK-No-8-ttg-Pelayanan-Kesehatan-SPApdf diakses : 20 November 2018

Puskesmas Mangkubumi 2018, Jumlah balita

Putri, Alias. (2009), Pijat dan senam bayi dan balita di Yogyakarta, Terdapat dalam : digilib.unisayogya.ac.id/1442/1/KHOIRUN \%_201210104171_Naskah\%publikasi.pdf diakses : 12 November 2018

Roesli. (2010), Pedoman pijat bayi, PT.Trubus agriwidya, Jakarta

Sekartini R, Adi NP (2006), Gangguan tidur pada anak usia bawah tiga tahun di lima kota di Indonesia. Sari pediatric, Terdapat dalam

https://saripediatri.org/index.php/saripediatri/article/download/33/767, diakses : 19 November 2018

Shofa L ( 2014 ), pengaruh pijat bayi terhadap kualitas tidur bayi usia 3-6 bulan di 
poliklinik kesehatan desa purworejo kecamatan boning kabupaten demak.

Siti M. (2015), Pengaruh pijat bayi terhadap kualitas tidur bayi didesa tabumela kecamatan tilanggo kabupaten gorontalo, Terdapat dalam kim.ung.ac.id/index.php/KIMFIKK/article/d ownload/11258/11131, diakses 26 November 2018

Siti R, Dkk. (2016 ), efektifitas baby spa terhadap lamanya tidur bayi usia 3-4 bulan di BPM bidan siti Fatimah kota cimahi tahun 2018

Subakti. (2008), keajaiban pijat bayi dan balita, PT wahyu media, Jakarta
Undang-undang Nomor 36 Tahun 2009 tentang kesehatan

Suwigno. (2010), penyimpangan tumbuh kembang anak RSUD di saetumu, Surabaya

Galenia MCC ( 2014 ) home baby spa " sentuhan ajaib untuk optimalkan kecerdasan dan tumbuh kembang buah hati", Agustus, . Bandung

Widodo, A. ( 2010 ), Efektivitas Baby spa terhadap lamanya tidur Bayi auasia 3-4 bulan.. Terdapat dalam : Publikasiilmiah.ums.ac.id/bitstrem/handl e/12345679 /3316/11.20Nov\%20WIDODO.pdf?sequ ence $=1$, diakses 20 November 2018 